\title{
Comparative Sustainability Analysis of Two Asian Cities: A Multidimensional Assessment of Taipei and Almaty
}

\author{
Stanislav E. Shmelev ${ }^{1}$, Rimma K. Sagiyeva ${ }^{2}$, Zhanar M. Kadyrkhanova ${ }^{3}$, \\ Yelena Y. Chzhan ${ }^{4}$, Irina A. Shmeleva ${ }^{5}$
}

Received: May 6, 2018 Revised: May 16, 2018 Accepted: July 30, 2018

\begin{abstract}
The article compares economic and environmental performance of Taipei and Almaty from the point of view of "green" economy, which is able to act as a key tool to ensure sustainable development of the region. As the comparison of the parameters of ecological and economic development of the Taipei and Almaty cities shows, they are similar in population size, but demonstrate completely different trends of sustainable development. Economic performance of the Taipei city is achieved with a decrease in the consumption of natural resources and the production of pollution, while the situation in Almaty is the opposite. Almaty maintains a high level of air pollution due to the use of coal in electricity production, as well as increased traffic and density of construction, including the southern part of the city, which is a zone for the transit of mountain air flows. The article discusses the activities jointly conducted by the Government of Taiwan and non-governmental organizations on environmental issues, as well as environmental NGOs, which resulted in significant improvements in the environmental field. Measures to stimulate the development and implementation of environmental innovations applied in the field of sustainable development in the city of Taipei can be adapted for the city of Almaty, where the environmental situation deteriorates year by year.
\end{abstract}

Keywords: sustainable development, green economy, modern cities, environmental problem, ecological innovation, Kazakhstan, Taiwan.

JEL Classification Code: F61, F62, F63, F64.

\section{Introduction}

Active and dynamic processes of globalization, international interaction, scientific and technical breakthroughs and the introduction of digital technologies in all spheres of the life of society exacerbate the contradictions between the economic

1 First Author. Director, Environment Europe Ltd., United Kingdom Email: director@environmenteurope.org or

Stanislav.shmelev@gmail.com

2 Professor, Dean, Higher School of Economics and Business, Al-Farabi Kazakh National University, Kazakhstan

Email: rimmasagiyeva@gmail.com

3 PhD student, Higher School of Economics and Business, Al-

Farabi Kazakh National University, Kazakhstan

Email: zhanar_5@mail.ru

4 Corresponding Author. Professor, Foreign Languages Department, Sarsen Amanzholov East-Kazakhstan State University, Kazakhstan [Postal Address: 72 Krylov Street., UstKamenogorsk, 070004, Kazakhstan] Email: elena_zhang@mail.ru

5 Associate Professor, Director, Institute of Design and Urban Studies, ITMO University, Saint Petersburg, Russia

Email: irina_shmeleva@hotmail.com or

i_a_shmeleva@corp.ifmo.ru and environmental trends in the development of regions and cities. The challenge of building green economy in Kazakhstan is magnified by the strong and established status of Kazakhstan as a resource exporting country. The volume of trade in Kazakhstan amounted to $\$ 55.4$ billion in 2017, including supplies of ferroalloys, petroleum products, copper, rolled metal, propane, butane and zinc. One third of the exported products represented the non-primary sector of the economy (MKKZ, 2017), including electric locomotives: assembled cars and electric batteries according to Zhenis Kasymbek, the Minister for Investment and Development of the Republic of Kazakhstan.

Dynamics of the economy in Kazakhstan is unfortunately accompanied by deterioration in the environmental quality in the regions of the country. An unsuitable ecological situation complicates the problem of stable territorial development. The high level of atmospheric air pollution in the cities of Kazakhstan with such pollutants as nitrogen dioxide, carbon monoxide, sulfur dioxide, hydrogen sulfide is caused by congestion of roads by urban transport, dissipation of emissions from industrial enterprises and low aerating in cities (Kazhydromet, 2017). Accounting for environmental factors in the development of regional programs, the rationale for investment policy, and the resolution of 
resource-saving issues is becoming increasingly important, since there is a close interconnection between the economic and environmental spheres that are the main components of sustainable territorial development.

The article will be structured as follows: Section 2 offers a conceptual framework of green economy in the urban sustainability context; Section 3 covers data and methods used; Section 4 presents the analysis and results of the study; Section 5 offers a discussion; Section 6 concludes.

\section{Conceptual Framework}

The notion of "sustainable development» is widely used in economics, ecology and other sciences, but until recently there has been no consensus on the nature and content of the term. Although there is an understanding in the world that «sustainable development is the basic paradigm of the further development of mankind in the twenty-first century» (Bobylev et al., 2015). After the global financial crisis of 2008-2009, the United Nations Environment Programme issued a proposal to use green economy as a key paradigm for economic reform, not only tackling the environmental issues through the development of renewable energy, circular economy and sustainable cities, but also stimulating economic progress through increased investment (UNEP, 2011; Shmelev, 2017).

The UN Conference on Sustainable Development in Rio de Janeiro, held in 2012, considered the following areas: the "green" economy in the context of sustainable development; institutional framework for sustainable development. The final document of the Rio +20 conference sets out the basis for a new model of green economic development that will promote social progress, sustainable consumption and production. Thus, the green economy concept, that has spread after the adopted "green economy approach to the sustainable development and poverty eradication" UN Environment Program (UNEP) in 2011, is positioned as a way to achieve sustainable development within global systems (UNEP, 2011). The transition to a green economy involves the use of clean energy and green technologies in production, reducing the negative impact on the environment and climate, and at the same time eradicating poverty.

The concept of sustainable development has been further clarified in the Agenda for Sustainable Development until 2030, adopted by the UN member states on September 25, 2015 (The Sustainable Development Goals (SDGs), officially known as the Transformation Our World: the 2030 Agenda for Sustainable Development until 2030). Seventeen goals were identified and expressed quantitatively in a number of indicators, which should be achieved within 15 years. It is clarified that joint efforts of governments, the private sector, civil society and the inhabitants of the Earth are needed to achieve the Sustainable Development Goals. Since there has been unprecedented urban growth in the world in recent decades and with about $54 \%$ of the world's population living there, there are also attendant problems of rapid urbanization: increasing number of slum dwellers, increasing air pollution, industrial and solid domestic waste, water pollution, etc. Therefore, Goal 11 on the Agenda for Sustainable Development until 2030 was defined as "Ensuring the openness, security, resilience and environmental sustainability of cities and human settlements" (UN, 2017). The urban slum population in developing countries declined from $39 \%$ in 2000 to $30 \%$ in 2014 . Despite some progress, the absolute number of urban residents living in the slums continued to increase, partly due to the acceleration of urbanization, the growth of the total population and the lack of sound land and housing policies. In 2014, it is estimated that 880 million urban dwellers lived in the slums, while in 2000 the number of such residents was 792 million.

As more and more people move to urban areas, the geographical boundaries of cities tend to expand to accommodate new residents. Between 2000 and 2015, the expansion of urban areas in all regions of the world was faster than the urban population growth. As a result, as cities grow, the population density decreases, while unplanned urban sprawl complicates the introduction of more sustainable urban development models. As of May 2017, 149 countries were engaged in the development of urban policies at the national level. One of the most important environmental services in cities is the safe disposal of solid waste. The unsuccessful solid waste disposal litter the gutters, cause flooding and can lead to the spread of diseases transmitted through water. Data from cities in 101 countries for the period from 2009 to 2013 indicate that the municipal waste collection system covered only $65 \%$ of the urban population. One of the main environmental risk factors for health is air pollution. In 2014, 9 out of 10 people living in cities breathed air that did not meet WHO's safety standard. The total area of the world's cities is only $3 \%$ of the Earth's land area, but they account for $60-80 \%$ of energy consumption and $75 \%$ of carbon dioxide emissions. Rapid urbanization rates have a negative impact on freshwater supplies, sewerage systems, habitat and public health systems. Relatively high density of cities can contribute to improving the efficiency of the economy and introducing technological innovations while reducing consumption of resources and energy (UN, 2017). Thus, SDGs openly acknowledged the need to take into account the interrelation between ecological and economic parameters of the development of modern cities, which has 
also been emphasized in the UN Indicators of Sustainable Development (UN, 2007).

There is a diversity of perspectives on green economy and sustainability that could be relevant for the urban context. Thus, Mayer and Knox (2006) use the urban regime change theory to characterise the transition of two German cities, Hersbruck and Waldirkch to the slow city and slow food movement. Shmelev and Shmeleva (2009) use multiple urban sustainability indicators to provide a comparative assessment of London and St Petersburg on social, economic and environmental dimensions. Shen et al. (2011) offer conceptual models of plastics recycling, the issue that is most pertinent today for urban centres all around the world. Yu et al. (2012) analyse $\mathrm{CO}_{2}$ emissions in Chinese cities and find that they are much higher than those of European counterparts, which is relevant for Kazakhstan, as Almaty, the focus of this paper, is extensively using coal as an energy source. Beatley and Newman (2013) propose a system of guidelines to define a 'biophilic' city or a city that values nature, ecosystems and biodiversity and show how such characteristics could benefit the wider well-being of an urban metropolis.

Höjer and Wangel (2014) consider Stockholm as a model for a smart and sustainable city, which uses ICT for the transition towards a green economy. David and Fistung (2015) consider transport policies in Romania that could be a useful experience of a situation in a country in transition, which could provide insights for Kazakhstan. Similarly, Cioca, et al. (2015) focus on Romania's $\mathrm{CO}_{2}$ emissions in the transport and energy sectors, industries and especially, waste management sector and argue for a transition towards the use of renewable resources at the national level, which could be most relevant for Kazakhstan as a country in transition. Shmelev (2017) applied the methodology of Multicriteria Decision Aid to a set of fourteen global cities and identified the leading position of Singapore compared with London, New York, Paris, Los Angeles, Shanghai, Tokyo and other global cities. Hemani and Punekar (2015) discuss new principles of urban design that could be crucial for a transition towards the green economy. Imai (2015) assesses green innovations in Japan from the point of view of patent applications and reveals that China starts playing a leading role in this area. Kumar et al. (2017) analyse how multi-criteria decision aid could be used to support introduction of renewable energy systems.

In the context of Kazakhstan, the research by Mukhtarova and Zhidebekkyzy (2015) shows that despite Kazakhstan's intentions to update and develop much of its infrastructure over the coming 20 years, inefficient use of resources is currently observed in every sector. The authors assert that it is necessary to encourage scientists and entrepreneurs to invent and commercialize new green technologies, which could be the basis for a successful transition to green economy. Most relevant new technologies for Kazakhstan are identified by Mukhtarova, Trifilova, and Zhidebekkyzy (2016), who identify the most relevant research on commercialization of green technologies, which forms a report on the existing practices and positive experience in responsible leadership for policy makers.

At the same time, the new era of Sustainable Development Goals (Biermann, Kanie, \& Kim, 2017) requires new interdisciplinary perspectives that should reflect as much as possible the different development goals, including goal 11 , specifically focused on urban sustainability. Beddoe et al. (2009) suggest an integrated set of worldviews, institutions, and technologies to stimulate and seed the evolutionary redesign of the current socio-ecological regime to achieve global sustainability. The urban research should also reflect the important dimensions of climate change, resource use and protection of ecosystems and biodiversity that have recently been the subject of global assessment, described in MCC (2017). The issues of sustainable consumption (Lorek \& Fuchs, 2011) also start playing a role in the context of a transition to a green economy, which in the context of Kazakhstan might be a very distant and abstract argument as residents primarily focus on how to increase consumption, not to decrease it.

Thus, urban sustainable development is a multifaceted and broadly interpreted phenomenon that integrates the economic, environmental and social components and requires interdisciplinary approaches. Green economy according to UNEP is the economy that leads to «improved human well-being and social equity, significantly reducing environmental risks and environmental deficits". In a new compendium, 'Green Economy Reader' (Shmelev, 2017) green economy is shown to be methodologically underpinned by the developments in ecological economics, an interdisciplinary field focusing on economy-environment interactions in the broadest sense. Ecological economics uses a wide spectrum of analytical tools to support decision making for sustainable development. Thus, the achievement of the goal of openness, security, vitality and environmental sustainability of cities and settlements assumes a comprehensive assessment of their environmental, social and economic development in comparison with the best world examples.

\section{Data and Methods}

It is well known that the ecological situation in the cities of the Republic of Kazakhstan is characterized by unfavorable parameters. In particular, if to look at the official statistics, the cities of the eastern region (Ust-Kamenogorsk, Ridder), the southern (Almaty, Shymkent, Kyzylorda, Taraz) and the 
central (Karaganda, Temirtau, Zhezkazgan), where the largest enterprises of metallurgy, chemistry and petrochemistry, heat-and-power enterprises are located, fall into the priority list of the cities with the highest pollution level (Ust-Kamenogorsk, 2016). The high level of pollution in these cities persists for many years, which indicates the need to strengthen environmental measures to improve the situation in the air. The level of atmospheric pollution is estimated from the complex index of atmospheric pollution (API-5), which is calculated from five substances (sulfur dioxide, carbon monoxide, nitrogen dioxide, phenol, formaldehyde) with the highest values at maximum permissible concentration (MPC) taking into account their hazard class. Depending on the API value, the level of air pollution is determined as follows: low less than or equal to 5 , increased - 5-7, high - 7-14, very high - greater than or equal to 14 (Kazinform, 2012). According to the Kazgidromet Regional State Enterprise data for 2014, the atmospheric pollution index (API-5) was 10.7 in Shymkent, 10.4 in Ust-Kamenogorsk and 10 in Almaty, which indicates a high level of pollution (State Fund of Ecological Information, 2015).

In order to understand what is the starting point for improving the ecological situation in particular in Almaty, it is necessary to get acquainted with the experience of leading cities, in which the development occurs in a more harmonious way, according to the principles of sustainable development, with equal attention given to economic, social and environmental dimensions. Based on the methodological ideas outlined in Shmelev and Shmeleva (2009) and Shmelev (2017) we have adopted a multi-criteria approach to try to determine the pressing urban development problems and sustainability potential of Almaty.

For comparison, we suggest considering the city of Taipei, one of the leading cities in South-East Asia, which demonstrates sustainable development, as environmental indicators do not deteriorate with dynamic and green economic growth. The choice is due to the fact that the cities are comparable in population: $2,704,810$ inhabitants in Taipei in 2015, (City Population, 2015), and 1,641,444 residents in Almaty (Committee on Statistics, 2017). In addition to the constantly growing population within the city limits, Almaty has become the core of the Almaty agglomeration with the population of $2,460,400$ people on January 1, 2015 (Committee on Statistics, 2017). At the same time, the area of Taipei is $271.8 \mathrm{~km}^{2}$ (Taipei City Government, 2015), while the area of Almaty is $683,5 \mathrm{~km}^{2}$ (Committee on Statistics, 2017). Figures 1 and 2 show maps of the Taipei and Almaty cities with public transport metro lines.

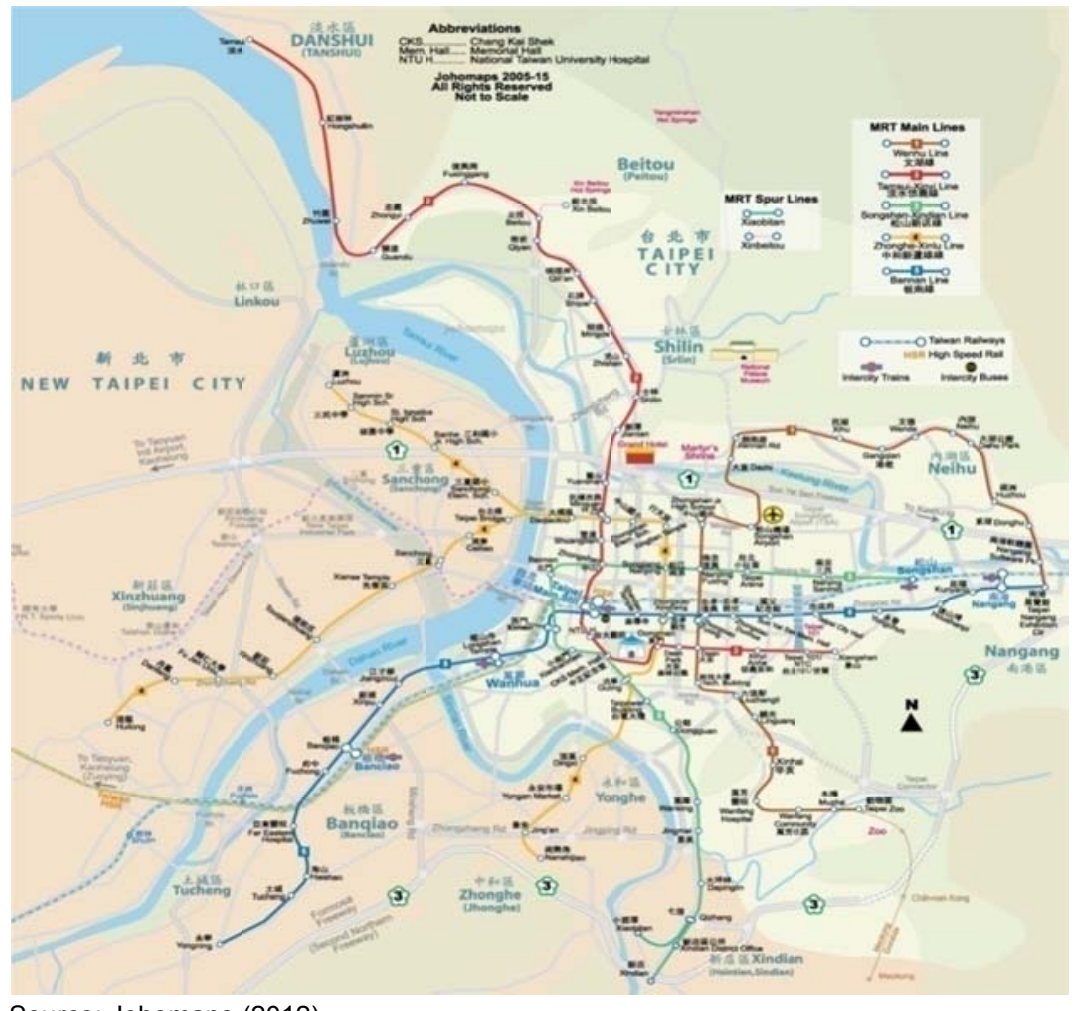

Source: Johomaps (2012).

Figure 1. Map of the Taipei city with metro lines. 


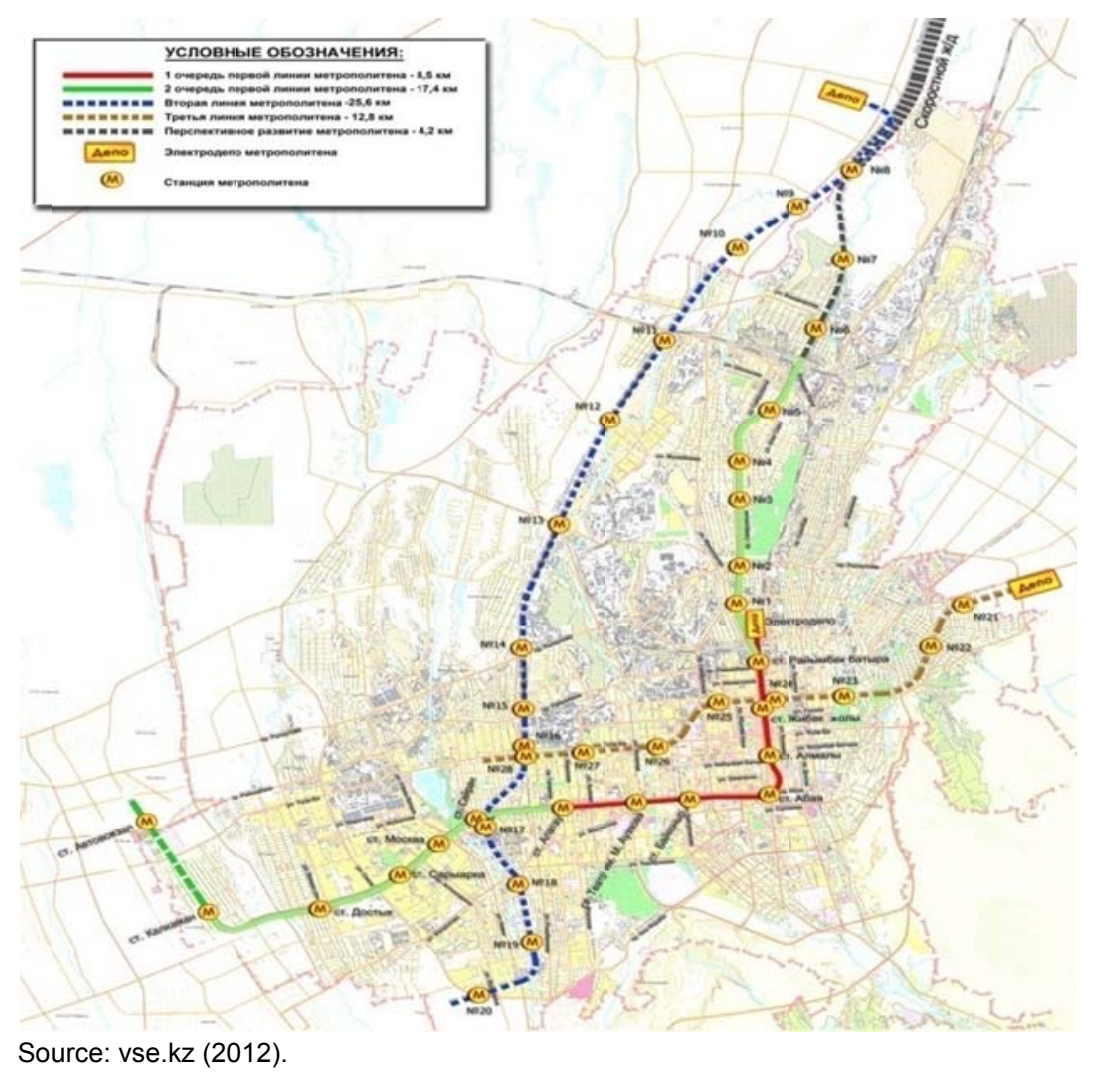

Figure 2. Map of the Almaty city with metro lines.

To analyse the ecological and economic situation in selected cities, we use sustainability indicators (Shmelev, 2011, 2012, 2017; Shmelev \& Shmeleva, 2009; Shmelev \& Rodriguez-Labajos, 2009), which will be conditionally divided into three major sectors:

- economic parameters that demonstrate the dynamics of the economy of these cities;

- social parameters associated with living conditions of the population;

- environmental parameters associated with the

consequences of economic activities for the environment

Table 1 presents the economic, social and environmental parameters for the cities of Taipei and Almaty for the year 2015.

Table 1. Economic, social and environmental parameters for the cities of Taipei and Almaty for the year 2015.

\begin{tabular}{|c|c|c|c|}
\hline № & Indicators & Taipei & Almaty \\
\hline & \multicolumn{3}{|l|}{ Economic parameters } \\
\hline 1 & Gross regional product & $\$ 44,173$ & $\$ 27,658.2$ \\
\hline 2 & $\begin{array}{l}\text { Number of metro stations per million } \\
\text { inhabitants }\end{array}$ & 43,26 & 5,72 \\
\hline 3 & $\begin{array}{l}\text { The share of public transport in the } \\
\text { city's total passenger traffic (\%) }\end{array}$ & 34 & 32 \\
\hline
\end{tabular}

\begin{tabular}{|c|l|c|c|}
\hline 4 & $\begin{array}{l}\text { The share of cycling in the city's total } \\
\text { passenger traffic (\%) }\end{array}$ & 4 & 1 \\
\hline 5 & Number of cars per 1000 people & 46 & 67 \\
\hline & Social parameters & \multicolumn{2}{|l|}{} \\
\hline 6 & Average monthly wage (in US dollars) & 1583 & 568 \\
\hline 7 & Unemployment (\%) & 3,8 & 5,5 \\
\hline 8 & Average life expectancy (years) & 80 & 74 \\
\hline 9 & $\begin{array}{l}\text { Patents for scientific research (per } \\
\text { capita). }\end{array}$ & 3,24 & 0,45 \\
\hline 10 & Gini index & 32,5 & 27,1 \\
\hline & Environmental parameters & 3 & 36 \\
\hline 11 & Sulfur dioxide $\left(\mathrm{SO}_{2}, \mathrm{mg}^{3} \mathrm{~m}^{3}\right)$ & 21,8 & 77 \\
\hline 12 & Nitrogen dioxide $\left(\mathrm{NO}_{2}, \mathrm{mg}^{3} \mathrm{~m}^{3}\right)$ & 41,7 & 120 \\
\hline 13 & $\begin{array}{l}\text { The amount of } \mathrm{PM}_{10}\left(\mu \mathrm{g} / \mathrm{m}^{3}\right), \text { standard } \\
20\end{array}$ & 326 & 226,5 \\
\hline 14 & The use of water (litres per day) & 3,62 & 12 \\
\hline 15 & «Green» spaces $\left(\mathrm{m}^{2}\right.$ percapita) & 101 & 409 \\
\hline 16 & $\begin{array}{l}\text { Amount of municipal waste generated } \\
\text { (kg/person per year) }\end{array}$ & 54 & 5 \\
\hline 17 & Recycling $(\%)$ & \\
\hline
\end{tabular}

Sources: Taipei City Government. https://english.gov.taipei/

Committee on Statistics of the Ministry of National Economy of the Republic of Kazakhstan. http://stat.gov.kz/ 


\section{Analysis and Results}

Comparative analysis of two cities, Taipei and Almaty, based on their sustainable development performance shows the following trends. The value of the gross regional product of the city of Taipei exceeds the GRP of Almaty by almost 1.5 times, which indicates the large scale of economic development in Taipei with a smaller population. The level of development of the city's infrastructure, which has positive environmental implications, can be judged by such indicators as the number of metro stations per million inhabitants (in Taipei they are 8 times more than in Almaty) and the share of bicycle transport in the overall passenger flow of the city (this figure in Taipei in 4 times exceeds the data of Almaty). At the same time, the share of public transport in the total city passenger traffic in the compared cities is approximately the same, and the number of cars per 1,000 people in Taipei is about 1.5 times less than in Almaty. Thus, the economy of Taipei city is developing dynamically, using more environmentally friendly transport, which significantly reduces the amount of harmful emissions to the atmosphere. How does Taipei manage to achieve a much stronger sustainable development performance with an area 2.5 times smaller than that of Almaty?

Exploring the number of patents for research, one could assess on the "innovation" of the city's economy, generating new ideas, since the development and implementation of know-how and technologies, in addition to progress, help create new jobs requiring qualitatively high level of skills, solve environmental and infrastructure problems, reduce the distribution of income between the rich and the poor. As can be seen from Table 1, the number of patents received for research work in Almaty shows a significant backlog - 0.5 patents per capita, while in Taipei this figure is 7 times higher. In fact, the southern capital of Kazakhstan, despite the considerable concentration of scientific potential of the country $(41 \%$ of the scientific sector employees are concentrated in Almaty), does not realize it effectively.

Turning to social performance indicators, let us examine the level of the average monthly wage - the main source of income for the population of cities. In the city of Taipei, this level is 2.7 times higher than that of Almaty. If we pay attention to real wages, then with inflation of $1.7 \%$ in Taipei and $7 \%$ in Almaty, we can state that the actual average standard of living of the Taipei population exceeds that of Almaty by a factor of 5 . Analysis of labour market statistics for both cities shows a greater number of unemployed in Almaty (5.5\%) than in Taipei (3.8\%), which also emphasizes better social and economic well-being of the latter city, since a significant part of the economically active population is engaged in creative production. The next criterion of social development is the average life expectancy at birth. In
Taipei, it is 6 years higher than in Almaty, which can also be associated with a higher level wellbeing of the population as well as better environmental quality.

If we consider another social indicator, such as the Gini index of income inequality, then in Almaty it is $27.1 \%$, which indicates a more even distribution of the income of the population in the megalopolis than in the city of Taipei, where it is $32.5 \%$. Meanwhile, if we look at additional statistics showing the level of incomes of the population in Almaty, such as the existence of savings and consumer loans, as well as the number of people owning real estate, then the problem of inequality gets a special meaning. The monetary policy pursued in Kazakhstan, in turn, influenced the incomes of the population (Kondybayeva and Ishuova, 2013). Thus, the proportion of citizens with a high standard of living and those who come in search of work and are severely restricted in funds is high in the city (in comparison with the average republican values). The problem of inequality is aggravated by employment and housing issues, which are often faced by new townspeople.

"Housing conflicts" and, in general, the problem of "unauthorised construction" also indicate a high level of inequality in Almaty. Many experts believe that housing issues can affect the growth of the conflict potential of the population (Zhusupova, 2015). At present, the problem is more acute, which is illustrated by the overpopulated Almaty, which does not have time to adapt the influx of migrants from rural areas of Kazakhstan (Zhusupova, 2015). It has to be noted that at its current official levels, inequality in Almaty is at the level of European cities and lower than in USA, China or South America. Thus, summing up the analysis, we can state that in the social sphere the city of Almaty lags far behind Taipei in accordance with the goals of sustainable development.

Considering the indicators that can describe the environmental performance of a city, first of all, let's pay attention to air quality. Concerning one of the most harmful emissions - sulfur dioxide $\left(\mathrm{SO}_{2}, \mathrm{mg} / \mathrm{m}^{3}\right)$ - average concentrations of this pollutant in Taipei are 12 times lower than in Almaty; the release of nitrogen dioxide $\left(\mathrm{NO}_{2}, \mathrm{mg} / \mathrm{m}^{3}\right)$ in Taipei demonstrates a value of 3 times less than in Almaty. Concentrations of particulate matter or $\mathrm{PM}_{10}$ (in $\mathrm{\mu g} / \mathrm{m}^{3}$, the WHO norm of 20 ), which according to $\mathrm{WHO}$ studies is directly affecting life expectancy, in Taipei are 3 times less than in Almaty (WHO, 2010). This disappointing fact is confirmed by the indicator of the average life expectancy (years) in the city of Almaty, which is 6 years shorter than in the city of Taipei.

A significant ecological criterion for sustainable development of the city is the indicator of water use (in liters per day), which is less by 100 liters per day in Almaty than in Taipei. However, "economical" water consumption in 


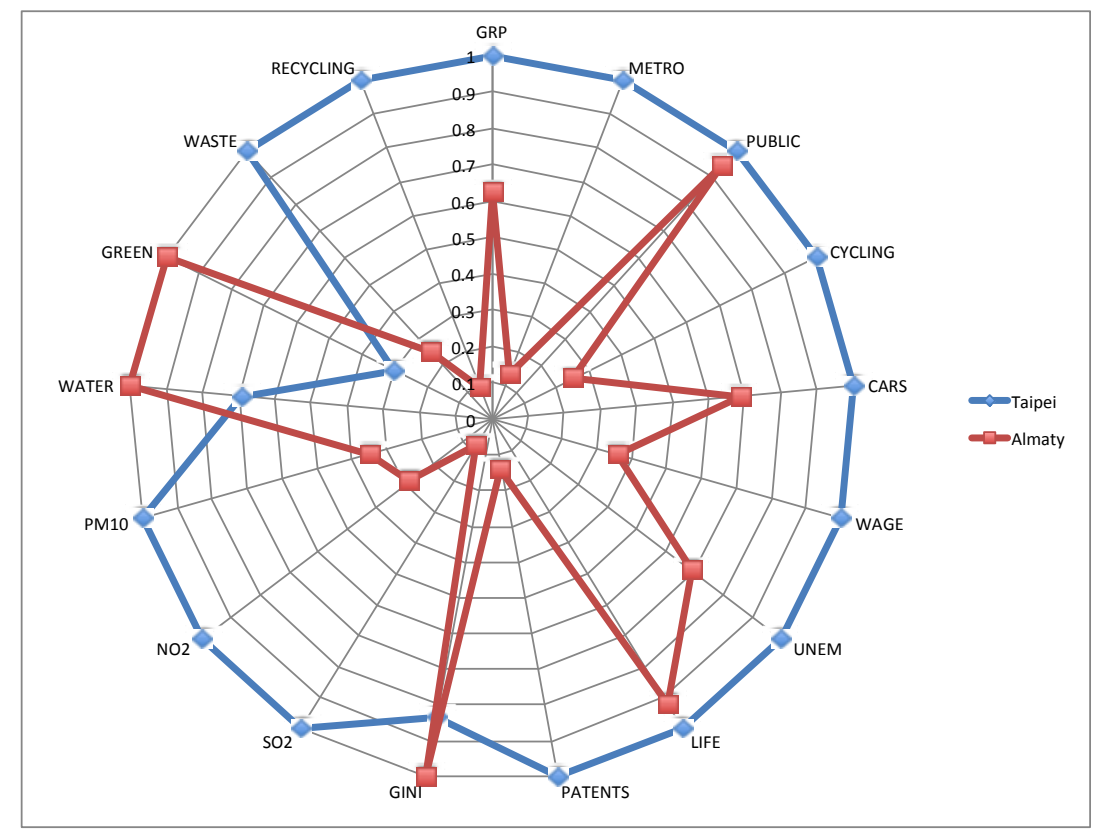

Figure 3. Comparative Analysis of Sustainability: Almaty and Taipei, 2015.

Almaty is not a result of the use of resource-saving technologies, but the lack of access of the population to the central water supply. The most favourable ecological indicator of the Kazakh city is the "green" spaces (in $\mathrm{m}^{2}$ per capita), which is 4 times more in Almaty than in Taipei. This is a great advantage of Almaty, because the presence of green spaces allows mitigating the ecological situation in the city, being a natural filter protecting the city's air. The two following indicators of the ecological well-being of cities - the volume of municipal waste and recycling (in percent) also show a significant backlog of the city of Almaty. The volume of municipal waste in Almaty is 4 times higher than in Taipei, with recycling lagging behind by a factor of 10 . Thus, the analysis of the ecological, economic and sociological parameters of the city of Taipei reflects its greater compliance with the goals of sustainable development. Figure 3 shows the Comparative Analysis of Sustainability: Almaty and Taipei, 2015.

It would be helpful to analyse how Taiwan managed to achieve its spectacular performance on sustainability. Turning to the history of Taiwan's environmental problems, back in the late 1990s, it was considered to be one of the most polluted regions in the world, neglecting environmental issues and increasing the number of industrial enterprises in an effort to increase employment and encourage exports.

First of all, experts noted particularly acute problems of garbage recycling, air and water pollution, which were caused by the high population density on the island in 1998, amounting to almost 580 people/ $\mathrm{km}^{2}$ (22 times more than in the US) with a total population of 21.82 million people. The number of industrial companies reached 157 thousand, and their density was 4.4 companies $/ \mathrm{km}^{2}$ (12 times more than in the US). At the same time, enterprises that used and produced harmful wastes had difficulty in disposing them. In turn, high population density led to a higher concentration of debris. The total amount of waste produced in Taiwan in 1996 was 8.6 million tons equivalent to more than 1 kilogram of garbage a day, comparable OECD (Organization of Economic Cooperation and Development) average. The total number of vehicles was 15.77 million units, including 5.35 million vehicles and 10.42 million motor scooters and motorcycles, which gives a density of 438 vehicles $/ \mathrm{km}^{2}$ (18 times more than in the US).

River and coastal waters in many parts of Taiwan have been severely contaminated, since industrial, agricultural and residential wastewater often directly merged into rivers. By 1997, $38 \%$ of Taiwan's main rivers and $29.5 \%$ of secondary rivers were polluted. The primary causes of the pollution problem were urban areas, mainly because the island did not have a modern sewerage system and wastewater treatment facilities. Even in Taipei, where the construction of the sewerage system began in 1972, only $40 \%$ of the sewage system was connected to it, residential buildings, in Kaohsiung - 5.3\% (Paley, 2003). The ecological problems of Taiwan were exacerbated by complex natural and climatic conditions, as the island is periodically exposed to such natural disasters as earthquakes, hurricanes, typhoons and droughts. Backed by the support of 
international organizations, the Government of Taiwan has taken a number of administrative, legislative and economic measures that have allowed the phased environmental problems to be addressed in stages, implementing "green" programs. It established the Environmental Protection Agency, invested significant funds and implemented a number of government programs aimed at addressing the problems of air quality, water pollution and recycling of waste. "Green" energy was one of the six priority industries, beginning in 2010 . The remaining five priority sectors are tourism, biotechnology, health, agriculture, creative and cultural industries.

In addition to actively participating in all international environmental agreements, Taiwan's environmental reforms were reinforced by the efforts of the business community. The Environmental Protection Agency formed working groups with representatives from 7 major industry sectors and held 17 meetings to discuss possible solutions and measures to overcome the difficulties in reducing emissions. The voluntary system for the reduction of carbon dioxide emissions is active in industries such as cement, steelmaking and petrochemical production, where from 2006 to 2015, more than 7,776 emission reduction measures were introduced. As a result of 42.1 billion NTD (about 1.3 billion US dollars) spent, the level of carbon dioxide emissions decreased by 10 million 220 thousand tons, and overall productivity increased. This indicates the effectiveness of interaction between the state and the private sector on the transition to an environmentally friendly production cycle (Radio Taiwan International, 2011).

The Government of Taiwan is continuously improving environmental legislation to prevent environmental crime. This is one of the few countries that have adopted legislation to reduce greenhouse gas emissions, entering into force in July 2015. In addition, the government has adopted a plan to reduce emissions by $50 \%$ by 2030 to 214 million tons, which would mean an actual reduction of $20 \%$. According to the Council for Agriculture, in Taiwan now more than 7,200 hectares of land are allocated for the cultivation of organic products. Over the past 10 years, the area of such fields has grown 3.5 times. The Government of Taiwan is carrying out activities to consolidate the efforts of the whole society to solve environmental problems. There's currently considerable public support for the governmental initiatives in the field of sustainability. Thus, the consistent and comprehensive implementation of measures by the government of Taiwan, continuing at this stage, has a positive economic, social and environmental effect in the city of Taipei, which will be extended to other regions of the country.

In 2011, according to the influential English news agency Economist Intelligence Unit, for active efforts to improve the quality of life of citizens and the urban environment, Taipei took 2nd place after Singapore among 22 Asian cities. The experts' report "Comparison of the "green" cities in Asia estimated the following indicators: energy and $\mathrm{CO}_{2}$ emissions, land use and architecture, transport, waste management, water resources, health infrastructure, air quality and environmental management. Together with Taipei, the second place was shared by Tokyo, Osaka, Yokohama, Hong Kong and Seoul. However, other regions of Taiwan have not achieved such excellent indicators, for example, Yunlin County is still the "champion" among all administrative-territorial units of Taiwan in terms of air pollution (Radio Taiwan International, 2011).

The Taiwan National Laboratory of Applied Research first demonstrated unmanned aerial vehicles for the study of typhoons. Six devices ordered in Australia in 2015 at a price of 81.5 thousand to 120 thousand dollars, will be used in the research program this year. They are equipped with video cameras and sensors to record data on temperature, humidity, air pressure, wind speed and direction. The maximum flight time of unmanned drones is from 10 to 18 hours (Radio Taiwan International, 2011). Also, Taipei introduces "smart", "green" power management. The company that manages the Taipei 101 skyscraper, which is officially certified as the world's tallest green, i.e. environmentally acceptable building, signed a memorandum of understanding with Siemens Ltd., Taiwan regarding the implementation of the energy complex management platform based on cloud technologies. This allows this building, which is a symbol and one of the main attractions of Taipei, to confidently embark on a path leading to its transformation into one of not only the most "green", but also the most intellectually advanced structures of the planet. According to the memorandum, "Taipei 101" will use the Siemens navigator to control the energy supply, energy consumption and operation of the building's entire power system, and also make detailed analytical reports based on the incoming data. All this should improve the efficiency of the building operation, reduce costs and promote the development of the strategy for managing the energy complex in the spirit of the concept of sustainable development.

In Kazakhstan, the Green Economy principles are gradually introduced into the development model by means of establishing new green institutions and joining international agreements, which play a very important role. The active participation of Kazakhstan country in international agreements in the field of environmental protection positively affected the solution of environmental problems. 


\section{Discussion}

Thus, comparing the effect of environmental reforms on sustainability performance of cities of Taipei and Almaty, the following differences can be noted:

- Commitment to the steady implementation of sustainable development programs in Taiwan was due to very acute environmental and natural conditions (such as lack of territory, political and socio-economic situation in Taiwan).

- The Government of Taiwan relied on technological, financial and institutional international cooperation with developed countries, both in the development and implementation of the strategy for sustainable development.

- The Government of Taiwan has provided various support for the transition of industrial enterprises to more environmentally friendly and energy-efficient technologies.

- The Government of Taipei has connected both the intellectual potential of the country and ordinary citizens, as well as non-governmental organizations to the implementation of green projects.

- Measures to stimulate the development and implementation of both national and foreign environmental innovations played a significant role.

- Legislation in the field of environmental protection has become tougher with respect to industries that cause damage to both the environment and the public.

In Kazakhstan, the transition to "green economy" is based on the following basic principles (President of Kazakhstan, 2013):

- increase of resource productivity, which is defined as GDP per unit of water, land, energy resources, unit of greenhouse gas emissions, etc. It should become the central economic indicator, as this parameter assesses the ability of our country to create value with minimizing the load on the environment;

- responsibility for the use of resources. It is necessary to increase the responsibility at all levels of government, business and the population for monitoring the sustainable consumption of resources and the state of the environment;

- modernization of the economy using the most efficient technologies. Kazakhstan will increase GDP, industrial production and the number of infrastructure facilities in the next 20 years. These transformations offer the possibility of applying completely new solutions in the economy: these can be new technologies, integrated systems with a closed production cycle, or innovative approaches to the production of electricity in the framework of the "Third Industrial Revolution";

- ensuring investment attractiveness of measures for efficient use of resources. It is necessary to ensure fair tariff and price formation in resource markets in order to reduce subsidies to the sectors that consume them;

- implementation of cost-effective activities in the first turn: priority will be given to those initiatives that allow not only to improve the environmental situation, but also to obtain economic benefits;

- training and formation of ecological culture in business and among the population: it is necessary to improve the existing ones and develop new educational programs on rational use of resources and environmental protection in the education and training system.

Thus, the idea of "green" economy is the basis for the long-term sustainability of economic development. At the same time, in the context of practical implementation of this idea, complex and integrated assessment of natural capital is based on traditional and new environmental and economic methods. To improve air quality in Almaty, a set of measures is required, both from the government and from the residents. The main sources of air pollution in the city are the emissions from CHPP (Coal Heat Power Plant), road transport and the private sector. Here is an outline of several proposed immediate steps that could be taken in the context of Almaty.

The Government may take the following measures: CHPP must be switched to natural gas, it is necessary to start using coal with ash content below $39 \%$, filters that are more efficient can also be installed. The largest point source of pollution is CHPP-2, which burns more than two million tons of coal annually. The quality of coal is low; this is Ekibastuz high-ash product, which when burned forms a large amount of useless ash. Some part of it is thrown through a high pipe into the atmosphere. It is also necessary to introduce a carbon tax on fuel, improve the quality of fuel sold in the city, transfer the private sector to gas heating; this will significantly reduce the amount of emissions in the air. The private sector also uses coal as fuel because it is cheaper than gas, but highly ashy. In addition, in private sector, people do not use filters, thereby contributing to the creation of urban smog. To solve the problem of air quality, the Government plans to allocate a budget for gas supply in 2019. "Samruk-Kazyna" JSC has started to develop a project on the transfer of CHPP-2 to gas; this is a very labour-consuming and costly process. These measures solve only $20 \%$ of the pollution problem. Residents should think about using environmentally friendly means of transportation, not burning rubbish and leaves. Cars certainly do not make the air cleaner. $80 \%$ of emissions 
comes from traffic; therefore, there is a need to solve the problem of traffic congestion: streamline the car flow, reduce the number of cars. This requires the political will of the city authorities. It is necessary to constantly monitor the level of emissions, which will predict the increase in permissible concentrations, evaluate the effectiveness of the measures taken, identify new harmful substances, and find the most dangerous and illegal sources of pollution. The air monitoring system in Kazakhstan requires modernization.

Authorities should listen to independent organizations and city activists who measure the level of pollution. More data on the state of the air are needed.

Kazhydromet is guided by the environmental code, where the rules for the implementation of environmental monitoring are prescribed. For example, all devices must have a certificate of compliance; in addition, all devices are regularly checked to verify serviceability or to set up correct functioning. If after monitoring we see a tenfold excess of the maximum permissible concentrations, which is called the "case of high pollution", then it is necessary to immediately send the data to the territorial Department of Ecology in order to identify the source of pollution and take action. People are not yet aware of the whole scale of the problem, because they simply do not have the time for that: they need to feed the children and pay the loans, while the issue of ecology is at a completely different level of the needs' pyramid. The media should bring the problem to people - to dig, conduct investigations, inform and find out where everything starts, why it happens and who should take responsibility.

Almaty has been balancing on the verge of ecological catastrophe for many years. A huge number of citizens come to polyclinics with complaints about respiratory organs The state in turn spends millions on their treatment, although it would be cheaper to eliminate the source of the problem. The pollution is incredibly higher than the maximum allowable concentration, and the authorities still do not pay proper attention to this problem. The best thing that Almaty residents can do is to demand from the municipal authorities affordable and practical public transport and developed bicycle infrastructure, as well as the convenient infrastructure for pedestrians (Ramazanova, 2017). Air pollution is the most important problem in Almaty and many cities in Kazakhstan. Of course, Almaty has other important problems like poor road system and public transport, overcrowded kindergartens and schools, criminalization and marginalization of the city, mass cutting down of trees and criminal seizure of the lands of the national park and reserves in the southern suburbs of the city, destruction of architectural monuments and cinemas for the construction of junk-food points in their place, etc.
The air problem by its neglect and scale exceeds all the other problems described above. There cannot be one solution to this issue; a complex of modern and effective measures is needed here. These could include many steps: choice in favour of grass, not asphalt; choice in favour of gas, not coal; choice in favour of eco-friendly transport, not fuming decommissioned Chinese buses; choice in favour of accessible galleries, independent cultural and educational centres, kindergartens and schools, and not in favour of shopping centres, gas stations, bookmakers and pubs; choice in favour of beautiful, honest and eco-friendly coat of arms with a snow leopard, glaciers, apple and flowers, not a monstrous acid logo. Almaty does deserve these proud symbols. After all, it was the Almaty land that gave the planet tulips and apple trees; expansion of public transport and reduction of the number of toxic vehicles; support for environmental art and culture; introduction of environmental standards, as well as air and fuel measurements - at the European level; returning to the values of the green city and trees, and not keeping to the barbarous practice of cutting down trees and reducing green zones and reserves; refusal to destroy environmentally friendly modes of transport (as was the case with the destruction of the Almaty tram system), in favour of introduction and expansion of clean modes of transport: trams, trolleybuses, bicycling; revival of the "lungs" of Almaty - the Kok-Zhailau National Park, rather than corrupt buildings and destruction of the reserve; expanding pedestrian alleys and parks, rather than highways and car interchanges; pedestrianisation, not car economy; ecological activism, ecological tourism.

Air pollution is an urgent problem throughout the Republic. One can see different kinds of smog in the cities of Kazakhstan: in Karaganda, Astana, Ust-Kamenogorsk, Pavlodar, Temirtau. Surprisingly and sadly, the political capital and the cultural capital compete in terms of air pollution with the level of pollution of industrial and toxic areas and even surpass them. This is not very compatible with expensive pomp and statements about innovation, green economy, the energy of the future and modernization of consciousness. Without clean air, our consciousness will most likely experience harmful mutations, and not transformation towards innovation and spiritual revival. Taking into account this sad fact, it is high time that everyone would understand the real scale of the problem, and start solving it and making the right choices.

\section{Conclusions}

The past history of Kazakhstan clearly illustrates the effect of a short-sighted approach, greed and ignoring ecological values combined with bad management in 
relation to cities and nature. Examples are abandoned ghost cities in central Kazakhstan, the Semipalatinsk nuclear test site, the desert where the Aral Sea used to splash, and many other places with polluted air and post-apocalyptic landscape. We would like Almaty to move towards Scandinavian environmental values, towards Brooklyn gentrification, towards Istanbul public transport and the Amsterdam bicycle system (Ramazanova, 2017). Thus, for the further sustainable development of Almaty, it is necessary to continue environmental reforms, stimulating production using green technologies, encouraging foreign and domestic eco-innovations, as well as connecting nongovernmental organizations and members of the public to support environmental reforms. Only consistent and systemic steps will help Kazakhstan's megalopolis move towards sustainable development.

\section{References}

Beatley, T., \& Newman, P. (2013). Biophilic Cities Are Sustainable, Resilient Cities. Sustainability, 5, 33283345. DOI:10.3390/su5083328.

Beddoe, R., Costanza, R., Farley, J., Garza, E., Kent, J., Kubiszewski, I., Martinez, L., McCowen, T., Murphy, K., Myers, N., Ogden, Z., Stapleton, K., \& Woodward, J. (2009). Overcoming systemic roadblocks to sustainability: The evolutionary redesign of worldviews, institutions, and technologies. PNAS, 106(8), 2483-2489.

Biermann, F., Kanie, N., \& Kim, R.E. (2017). Global governance by goal-setting: the novel approach of the UN Sustainable Development Goals. Current Opinion in Environmental Sustainability, 1, 26-27.

Bobylev, S., Zubarevich, N., \& Solovyova, S. (2015). Challenges of the crisis: how to measure the sustainability of development? Voprosy Ekonomiki, 1 147-160.

Cioca, L.-I., Ivascu, L., Rada, E.C., Torretta, V., \& Ionescu, G. (2015). Sustainable Development and Technological Impact on $\mathrm{CO}_{2}$ Reducing Conditions in Romania. Sustainability, 7, 1637-1650. DOI:10.3390/su7021637.

City Population. (2015). Taiwan: Counties and Cities. Retrieved May 15, 2018, from http://www.citypopulation.de/Taiwan-Cities.html/2015

Committee on Statistics. (2017). Department of Statistics of the City of Almaty, Ministry of National Economy of the Republic of Kazakhstan. Retrieved May 15, 2018, from http://stat.gov.kz/

David, L., \& Fistung, F.D. (2015). Scientific research support in developing sustainable transport in Romania.
World Review of Science, Technology and Sustainable Development, 12(1), 49-66.

Demographic Yearbook of Almaty. (2017). Ministry of National Economy of the Republic of Kazakhstan Committee on Statistics. Statistics Department of Almaty. Retrieved May 15, 2018, from http://www.stat.gov.kz/almaty

Domini Anno. (2012). The scheme of the Almaty Metro. Retrieved May 15, 2018, from https://vse.kz/topic/ 490373-metro-almaty-chast-2/2012/02/01

Hemani, S., \& Punekar, R.M. (2015). Design education for sustainability: a case study for an inclusive approach to design in India. World Review of Science, Technology and Sustainable Development, 12(1), 29-48.

Höjer, M., \& Wangel, J. (2014). Smart Sustainable Cities: Definition and Challenges. ICT Innovations for Sustainability. Advances in Intelligent Systems and Computing 310 (pp. 1-15). Springer International Publishing.

Imai, K. (2015). International market competitiveness of Japanese green innovation technologies: an analysis using patent data. World Review of Science, Technology and Sust. Development, 12(1), 77-94.

Johomaps. (2012). Metro Map of Taipei. Retrieved May 15, 2018, from http://johomaps.com/as/taiwan/taipei/ taipeimetro.html

Kazhydromet. (2017). Information Bulletin "On the State of the Environment of the Republic of Kazakhstan for 2017", Ministry of Energy of the Republic of Kazakhstan, "Kazhydromet" RSE, Department of Environmental Monitoring. Retrieved May 15, 2018, from https://kazhydromet.kz/upload/pdf/en_151678 8286.pdf

Kazinform. (2012). The atmospheric pollution index in Almaty decreased by 2.8 units. Retrieved May 15 , 2018, from http://www.inform.kz/ru/indekszagryazneniya-atmosfery-v-almaty-snizilsya-na-2-8edinicy_a2501100/

Kondybayeva, S., \& Ishuova, Z. (2013). The Effect of Monetary Policy on Real House Price Growth in the Republic of Kazakhstan: A Vector Autoregression Analysis. World Applied Sciences Journal, 22(10), 1384-1394.

Kowarsch, M., \& Jabbour, J. (2017). Solution-oriented global environmental assessments: Opportunities and challenges. Environmental Science and Policy, 77, 187-192.

Kumar, A., Sah, B., Singh, A.R., Deng, Y., He, X., \& Kumar, P., \& Bansal, R.C. (2017). A review of multi criteria decision-making (MCDM) towards sustainable 
renewable energy development. Renewable and Sustainable Energy Reviews, 69, 596-609.

Lorek, S., \& Fuchs, D. (2011). Strong sustainable consumption governance - precondition for a degrowth path? Journal of Cleaner Production, 30, 18. DOI:10.1016/j.jclepro.2011.08.008.

Mayer, H., Knox, \& Paul L. (2006). Slow cities: sustainable places in a fast world. Journal of Urban Affairs, 28(4), 321-334.

MKKZ. (2017). Kazakhstan exports more than 800 kinds of goods to 113 countries. Retrieved May 15, 2018, from http://mk-kz.kz/articles/2017/11/21/kazakhstaneksportiruet-bolee-vidov-800-tovarov-v-113-stranmira.html

Mukhtarova, K.S., \& Zhidebekkyzy, A. (2015). Development of Green Economy via Commercialization of Green Technologies: Experience of Kazakhstan. Journal of Asian Finance, Economics and Business, 2(4), 21-29. DOI: 10.13106/jafeb.2015.vol2.no4.21.

Mukhtarova, K.S., Trifilova, A.A., \& Zhidebekkyzy, A. (2016). Commercialization of Green Technologies: an Exploratory Literature Review. Journal of International Studies, 9(3), 75-87. DOI: $10.14254 / 2071-8330.2016 / 9-3 / 6$.

Paley, T.L. (2003). Environmental security in Taiwan: problems and solutions. Experience and traditions of ethnic wildlife management, Ulan-Ude. Retrieved May 15, 2018, from http://world.lib.ru/p/ palej_t_l/ecolog.shtml

Pchelyanskaya, I. (2017). What is wrong with the air of Almaty? Retrieved May 15, 2018, from https://krisha.kz/content/articles/2017/chto-ne-tak-svozduhom-almaty

President of Kazakhstan. (2013). Decree of the President of the Republic of Kazakhstan "Concept for the transition of the Republic of Kazakhstan to Green Economy. Plan of measures for the implementation of the Concept for 2013-2020". Retrieved May 15, 2018, from https://greenkaz.org/images/fornews/pdf/ npa/koncepciya-po-perehodu.pdf

Radio Taiwan International. (2011). News. Media Review. Taiwan Ecology. Retrieved May 15, 2018, from http://english.rti.org.tw/

Ramazanova, U. (2017). Attention, disaster: what happens to the air of Almaty? Retrieved May 15, 2018, from http://www.the-village.kz/village/city/situation/827zagryaznenie-vozduha/

Shen, L., Nieuwlaar, E., Worrell, E., \& Patel, M. K. (2011). Life cycle energy and GHG emissions of PET recycling: change-oriented effects. International
Journal of Life Cycle Assessment, 16, 522-536. DOI 10.1007/s11367-011-0296-4.

Shmelev, S.E, \& Rodriguez-Labajos, B. (2009). Dynamic multidimensional assessment of sustainability at the macro level: The case of Austria. Ecological Economics, 68(10), 2560-2573.

Shmelev, S.E. (2011). Dynamic Sustainability Assessment: The Case of Russia in the Period of Transition (1985-2007). Ecological Economics, 70(11), 20392049.

Shmelev, S.E. (2012). Ecological Economics: Sustainability in Practice. Springer.

Shmelev, S.E. (2017). Multidimensional Sustainability Assessment for Megacities. In Shmelev, S.E. (ed) (2017) Green Economy Reader: Lectures in Ecological Economics and Sustainability, Springer, pp. 205-236

Shmelev, S.E., \& Shmeleva, I.A. (2009). Sustainable cities: problems of integrated interdisciplinary research, Inderscience. International Journal of Sustainable Development, 12(1), 4-23.

State Fund of Ecological Information. (2016). National report on the state of the environment and the use of natural resources of the Republic of Kazakhstan for 2011-2014. Retrieved May 15, 2018, from http://new.ecogosfond.kz/wp-content/uploads/2016/ 08/NDSOS_2011-2014.pdf

Taipei City Government. (2015). Government. Administrative Districts. Retrieved May 15, 2018, from https://english.gov.taipei/

UN. (2007). Indicators of Sustainable Development: Guidelines and Methodologies, Third Edition, New York. Retrieved May 15, 2018, from http://www.un.org/esa/sustdev/natlinfo/indicators/gui delines.pdf

UN. (2017). Progress towards the Sustainable Development Goals, Report of the Secretary-General, Economic and Social Council, E/2017/66. Retrieved May 15, 2018, from https://unstats.un.org/sdgs/files/report/ 2017/secretary-general-sdg-report-2017-EN.pdf.

UNEP. (2011). Towards Green Economy: Pathways To Sustainable Development and Poverty Eradication. Retrieved May 15, 2018, from http://drustage.unep.org/greeneconomy/sites/unep.or g.greeneconomy/files/field/image/green_economyrep ort_final_dec2011.pdf

Ust-Kamenogorsk. (2016). The development program of the territory of Ust-Kamenogorsk city for 2016-2020. N8/3-VI. Retrieved May 15, 2018, from http://oskemen.vko.gov.kz./ru/programm1.htm 
WHO. (2010). Health topics. Environment and health. Air quality. Data and statistics. Retrieved May 15, 2018 from http://www.euro.who.int/en/health-topics/ environment-and-health/air-quality/data-andstatistics/

Yu, W., Pagani, R., \& Huang, L. (2012). $\mathrm{CO}_{2}$ emission inventories for Chinese cities in highly urbanized areas compared with European cities. Energy Policy, 47, 298-308.
Zhusupova, A. (2015). Dynamics of social inequality in Kazakhstan. Institute of World Economy and Politics (IWEP) under the Foundation of the First President of the Republic of Kazakhstan - the Leader of the Nation.-Astana-Almaty. Retrieved May 15, 2018, from http://iwep.kz/files/attachments/article/20160921/dinamika_socialnogo_neravenstva_v_kazahsta ne.pdf 